Article

\title{
Effect of High Temperature on the Mechanical Properties of Steel Fiber-Reinforced Concrete
}

\author{
Augusto C. S. Bezerra ${ }^{1,2}, * \mathbb{D}$, Priscila S. Maciel ${ }^{2}$, Elaine C. S. Corrêa ${ }^{1}$, Paulo R. R. Soares Junior ${ }^{1}$, \\ Maria T. P. Aguilar ${ }^{3}$ and Paulo R. Cetlin ${ }^{4}$ \\ 1 Department of Materials Engineering, Federal Centre for Technological Education of Minas Gerais, \\ Belo Horizonte, MG 30421-169, Brazil; elainecarballo@cefetmg.br (E.C.S.C.); \\ pauloroberto.rsoares@gmail.com (P.R.R.S.J.) \\ 2 Department of Transports Engineering, Federal Centre for Technological Education of Minas Gerais, \\ Belo Horizonte, MG 30421-169, Brazil; pmaciel@ymail.com \\ 3 Department of Materials Engineering and Civil Construction, Federal University of Minas Gerais, \\ Belo Horizonte, MG 31270-901, Brazil; teresa@ufmg.br \\ 4 Department of Mechanical Engineering, Federal University of Minas Gerais, Belo Horizonte, MG 31270-901, \\ Brazil; pcetlin@demec.ufmg.br \\ * Correspondence: augustobezerra@cefetmg.br; Tel.: +55-31-3319-7119
}

Received: 17 September 2019; Accepted: 17 November 2019; Published: 21 November 2019

\begin{abstract}
The effect of high temperature on the mechanical properties of concrete reinforced by steel fibers with various aspect ratios has been investigated in this study. Concrete specimens were fabricated from four different concrete mixtures and cured for 28 days. After curing and natural drying, the specimens were annealed at a temperature of $500^{\circ} \mathrm{C}$ for $3 \mathrm{~h}$ in an electric furnace. The compressive and tensile strengths as well as the elastic moduli of the produced specimens were determined. It was found that the mechanical properties (especially flexural toughness) of steel fiber-reinforced concrete were less affected by high temperature as compared to those of control concrete specimens. The flexural tensile strength of fiber-reinforced concrete measured after high-temperature treatment was almost equal to the value obtained for the reference concrete specimen at room temperature. It should be noted that the addition of steel fibers to concrete preserves its mechanical properties after exposure to a temperature of $500{ }^{\circ} \mathrm{C}$ due to fire for a period of up to $3 \mathrm{~h}$, and thus is able to improve its high-temperature structural stability. The test results of this study indicate that the use of steel fibers in concrete-based materials significantly enhances their fire and hear-resistant characteristics.
\end{abstract}

Keywords: mechanical properties; steel fiber; high temperature; concrete

\section{Introduction}

Fibers have been used to reinforce brittle materials before the invention of cement and since the time of the Egyptian and Babylonian civilizations [1]. In 1960, multiple studies were performed to improve the mechanical properties of concrete by incorporating different types of fibers [2-6] into its structure, which healed cracks and increased the ductility of concrete elements [7]. Furthermore, the addition of fibers to a concrete matrix increased the strain at peak load and enhanced the energy absorption ability of fabricated structures [8]. Many research groups have studied the properties of various composites produced by fiber insertion, which included cement-based materials reinforced with agro-industrial residual, recycled polyethylene terephthalate, vegetal, glass, and steel fibers [9-12]. In particular, the addition of fibers to a concrete matrix improved its durability by exhibiting pseudo-ductile behavior (residual strength to applied force after cracking). The addition of fibers to a composite matrix increases its energy absorption capacity, because they promote the stress transfer through cracks by acting 
as bridges and thus increase the material stability [13-16], owing to the fiber's characteristics, the properties of the concrete matrix, and fiber-matrix interactions [15]. The efficiency of the added fibers depends on their specific parameters such as volume fraction, aspect ratio (AR), shape, and size distribution [17]. In addition to cementitious materials, various other composites may also be reinforced by fibers, for example asphalt mixtures [18], polymers [19,20], or ceramic matrix [21].

Studies involving steel fibers for the reinforcement of cementitious materials (mainly concrete) and their applications have become increasingly present in the scientific community. Kotsovos, Zeris, and Kotsovos [22] studied the effect of steel fibers on reinforced concrete structures during earthquake simulation. Chalioris and Sfiri [23] evaluated the shear behavior of steel fiber-reinforced beams under cyclic loading. Chalioris [24] performed a consistent analytical approach to determine the minimum fiber content in steel fibrous concrete beams that would lead to adequate shear strength and consequent stirrup replacement. Park et al. [25] studied the influence of curing conditions on the compressive strength at early ages of ultrahigh-performance steel fiber-reinforced concretes. Kang et al. [26] investigated the microstructural properties of fiber-reinforced ultrahigh-performance concretes submitted to different heat treatments. Chalioris and Panagiotopoulos [27] evaluated the flexural response of steel fiber-reinforced concrete (SFRC) by a numerical approach. Guerini et al. [28] studied the effect of steel fibers and synthetic macrofibers on the workability and mechanical performance of concrete. Chalioris, Kosmidou, and Karayannis [29] investigated the influence of steel fiber addition on the mechanical behavior of reinforced beams submitted to cyclic loading. Soares Junior et al. [30] studied the performance of steel fiber-reinforced high-performance cementitious composite plates through bending behavior, statistical analysis, and microstructural investigation. Workability was evaluated in other works [31-34]. In general, as fiber content increases, workability decreases. Admixtures, additives, fiber type, and mix proportion also affect the properties of the fiber-reinforced concretes (FRC) in the fresh state.

The properties of concrete may be significantly influenced by high temperatures [35,36], which cause a decrease in its compressive strength as well as cracking and spalling. In addition, high temperatures reduce the bond strength between the cement paste and aggregates and lead to the progressive breakdown of the cement gel structure, which consequently reduces its load-bearing capacity $[37,38]$. Multiple studies of the mechanical properties of steel and polypropylene (FRC) exposed to high temperatures have been performed [39-48]; the strength reduction and surface cracking phenomena observed for various fiber-reinforced concrete are described in detail in [49].

However, the investigation of concrete deterioration at high temperatures represents a challenging task because of the different properties of its constituents [50]. The negative effects of high temperature on the microstructure (thermochemical decomposition and excessive microcracking) and macrostructure (abrasion and spalling) of concrete substantially decrease its strength and elasticity modulus. Furthermore, the strength of cement paste decreases after heating to temperatures above $300{ }^{\circ} \mathrm{C}$ due to the loss of water by hydrated silicate species (the process is accelerated in the temperature region between 500 and $600^{\circ} \mathrm{C}$ because of the calcium hydroxide dehydration). As a result, the cement starts shrinking [51]. For temperatures below $200{ }^{\circ} \mathrm{C}$, the strength reduction of the cement is relatively insignificant. In the region from $200^{\circ} \mathrm{C}$ to $300^{\circ} \mathrm{C}$, the weakening of the van der Waals forces between various $\mathrm{C}-\mathrm{S}-\mathrm{H}$ layers occurs because of the water evaporation (both these factors contribute to the loss of concrete strength) $[50,52]$. In the temperature region from $300{ }^{\circ} \mathrm{C}$ to $600{ }^{\circ} \mathrm{C}$, the corresponding reduction in strength amounts to $50 \%-90 \%$. Between $600{ }^{\circ} \mathrm{C}$ and $900{ }^{\circ} \mathrm{C}$, the related strength reduction becomes equal to $90 \%[50,51,53]$. At temperatures above $1000{ }^{\circ} \mathrm{C}$, its residual strength is reduced to zero [50]. However, the structural resistance of concrete become zero after heating to temperatures above $600{ }^{\circ} \mathrm{C}$ [54]. At a temperature of $500{ }^{\circ} \mathrm{C}$, the concrete suffers a $55 \%-70 \%$ loss of its initial strength [55].

In the application scenario, FRC can be used in various situations, structural or not, such as industrial floors, prefabricated elements, slabs, pillars, foundations, etc. [56,57]. Other specific applications also occur, especially for high-fiber contents such as structures that are capable of 
withstanding earthquakes [22], impact resistance [58], ballistic defense, and explosions [59]. However, the advantageous characteristics of FRC exposed above are favorable in fire situations. Structures can be suddenly taken over by fires, which puts lives at risk and causes extensive financial impacts. The use of fibers promotes good resistance at elevated temperatures, avoids spalling, and restricts dimensional variations, keeping the concrete cohesive [60]. Fire suitability is essentially relevant in modular buildings [61], in which different types of composite materials are used [62] (glass fiber-reinforced polymer-GFRP; polymer or steel mesh-reinforced cementitious plate), and in railway infrastructure constructions [63]. In the first case, modular buildings are constructed by combining large prefabricated parts or elements, so there is a need for additional concern with thermal acoustic insulation and fire resistance. The second point concerns the possibility of burning the railway superstructure sleepers in case of fire or the welding of rail joints.

In this context, the study of building materials subjected to high temperatures is important, especially those that have structural function. In addition, it was observed that temperatures around $500{ }^{\circ} \mathrm{C}$ are critical in terms of degradation of the cementitious matrix and consequent drop in performance. As stated above, several works address the performance of fiber-reinforced concrete subjected to elevated temperatures. However, the combined effect of the fiber aspect ratio and high temperature on mechanical behavior needs to be further investigated. Thus, the present work aims to investigate the influence of the addition of steel fibers and their respective aspect ratio on the mechanical strength of concrete heated at $500^{\circ} \mathrm{C}$.

There are several studies in the literature related to the addition of steel fibers in concrete for use in floors and slabs, but there are few studies on steel fiber-reinforced concrete in fire situations. The present work contributed to the scientific development of concrete technology on the aspect of durability in demands after submission to high temperatures. The results presented show the gains caused by the addition of steel fibers in concrete, especially in situations after exposure to high temperatures.

\section{Materials and Methods}

Figure 1 shows the flowchart of the experimental procedure utilized for the characterization of Portland cement and its aggregates. In this study, concrete specimens with and without steel fibers were prepared. Tables 1-3 list the characteristics of the cement, fibers, and raw materials, respectively; Table 4 specifies the proportions of the raw materials; and Table 5 describes the chemical composition of the fibers.

Table 1. Properties of Portland cement used in this study.

\begin{tabular}{|c|c|c|c|c|c|c|c|}
\hline \multicolumn{3}{|c|}{ Physical } & \multicolumn{3}{|c|}{ Mechanical } & \multicolumn{2}{|c|}{ Chemical (wt \%) } \\
\hline \multirow{3}{*}{ Particle size } & \#200-75 mm (\%) & 0.28 & \multirow{4}{*}{$\begin{array}{l}\text { Compressive } \\
\text { strength }(\mathrm{MPa})\end{array}$} & $1 \mathrm{~d}$ & 25.7 & Insoluble residue & 0.72 \\
\hline & \#325-45 mm (\%) & 2.75 & & $3 \mathrm{~d}$ & 36.1 & Loss on ignition & 3.79 \\
\hline & Blaine $\left(\mathrm{cm}^{2} / \mathrm{g}\right)$ & 5.232 & & $7 \mathrm{~d}$ & 41.2 & $\mathrm{MgO}$ & 2.91 \\
\hline Density $\left(\mathrm{g} / \mathrm{cm}^{3}\right)$ & & 3.070 & & $28 \mathrm{~d}$ & 49.7 & $\mathrm{SO}_{3}$ & 3.63 \\
\hline \multirow{2}{*}{$\begin{array}{l}\text { Setting time } \\
\quad(\min )\end{array}$} & Initial & 130 & \multirow{2}{*}{$\begin{array}{l}\text { Expansibility } \\
(\mathrm{mm})\end{array}$} & Cold & - & & \\
\hline & Final & 160 & & Hot & 0.4 & & \\
\hline
\end{tabular}

Table 2. Properties of the steel fibers used in this study.

\begin{tabular}{ccccccc}
\hline Notation & $\begin{array}{c}\text { Manufacturing } \\
\text { Material }\end{array}$ & Type & Section & $\begin{array}{c}\text { Diameter (d) } \\
(\mathbf{m m})\end{array}$ & $\begin{array}{c}\text { Length (1) } \\
(\mathbf{m m})\end{array}$ & $\begin{array}{c}\text { Aspect Ratio (AR) } \\
\text { (l/d) }\end{array}$ \\
\hline AR 44 & $\begin{array}{c}\text { Drawn low-carbon } \\
\text { steel wire }\end{array}$ & Hooked & Circular & 0.75 & 33.00 & 44 \\
\hline AR 67 & $\begin{array}{c}\text { Drawn low-carbon } \\
\text { steel wire }\end{array}$ & Hooked & Circular & 0.75 & 50.00 & 67 \\
\hline AR 80 & $\begin{array}{c}\text { Drawn low-carbon } \\
\text { steel wire }\end{array}$ & Hooked & Circular & 0.75 & 60.00 & 80 \\
\hline
\end{tabular}




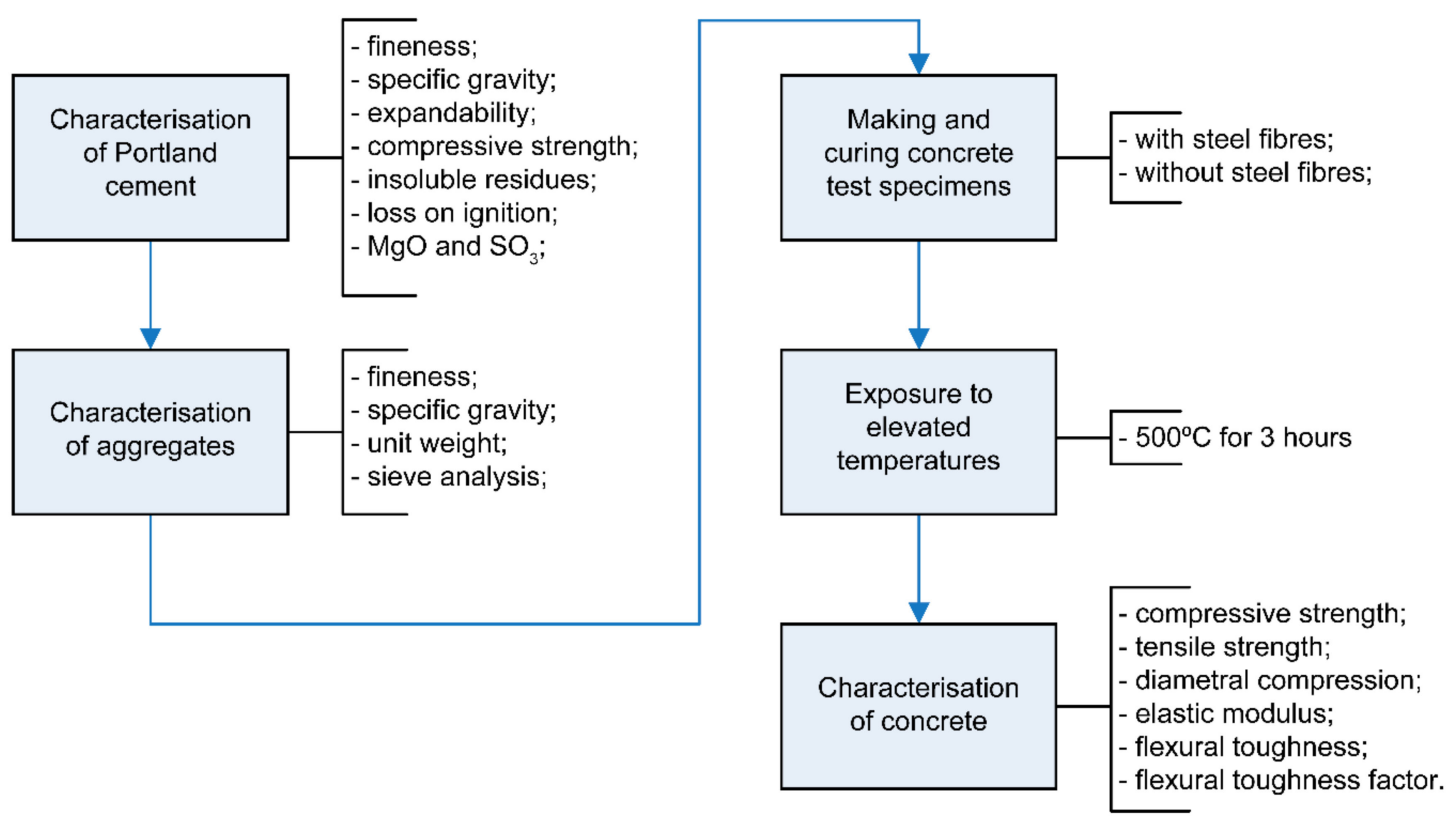

Figure 1. A flowchart describing the experimental procedure used to characterize Portland cement and its aggregates.

Table 3. Parameters of the raw materials used for concrete preparation in this study.

\begin{tabular}{ccccc}
\hline Component & Description & $\begin{array}{c}\text { Density } \\
\mathbf{( k g / \mathbf { d m } ^ { 3 } \mathbf { ) }}\end{array}$ & $\begin{array}{c}\text { Unit Weight } \\
\left(\mathbf{k g} / \mathbf{d m}^{3} \mathbf{)}\right.\end{array}$ & Finesses \\
\hline Binder & High early strength Portland cement & 3.070 & - & - \\
Fine aggregates & Sand & 2.591 & 1.541 & 2.672 \\
Coarse aggregates & Crushed limestone (Max size: $19 \mathrm{~mm})$ & 2.692 & 1.503 & 5.966 \\
Water & - & - & - & - \\
\hline
\end{tabular}

Table 4. Parameters of the concrete mixtures utilized in this study.

\begin{tabular}{cccc}
\hline Component & Description & Content $\mathbf{( k g} / \mathbf{m}^{\mathbf{3}}$ ) & Proportion $\mathbf{( k g )}$ \\
\hline Binder & High early strength Portland cement & 391.5 & 1.00 \\
Fine aggregates & Sand & 742.0 & 1.90 \\
Coarse aggregates & Crushed limestone & 972.5 & 2.49 \\
Water (w/c = 0.55) & - & 214.8 & 0.55 \\
Fibers (1\% by volume) & Steel fibers & 81.2 & 0.21 \\
\hline
\end{tabular}

Table 5. Chemical composition of the steel fibers used in this study.

\begin{tabular}{ccccccc}
\hline Element & \%Fe & \%C & \%Mn & \%Si & \%P & $\% \mathbf{S}$ \\
\hline Specification & $>99.19$ & $0.06 \% \max$ & $0.25 \%$ to $0.40 \%$ & $0.10 \%$ to $0.30 \%$ & $0.025 \% \max$ & $0.025 \% \max$ \\
\hline
\end{tabular}

The concrete specimens without fibers will be further referred to as control concrete (CC), and the steel fiber-reinforced concrete (SFRC) specimens were found to be dependent on the AR of their fiber components. Four prismatic specimens with dimensions of $150 \times 150 \times 500 \mathrm{~mm}$ and 20 cylindrical specimens with diameters of $100 \mathrm{~mm}$ and heights of $200 \mathrm{~mm}$ were molded. A half of the prepared specimens were heated to a high temperature after $7 \mathrm{~d}$ of $28 \mathrm{~d}$ humid curing in accordance with the diagram presented in Figure 2. 


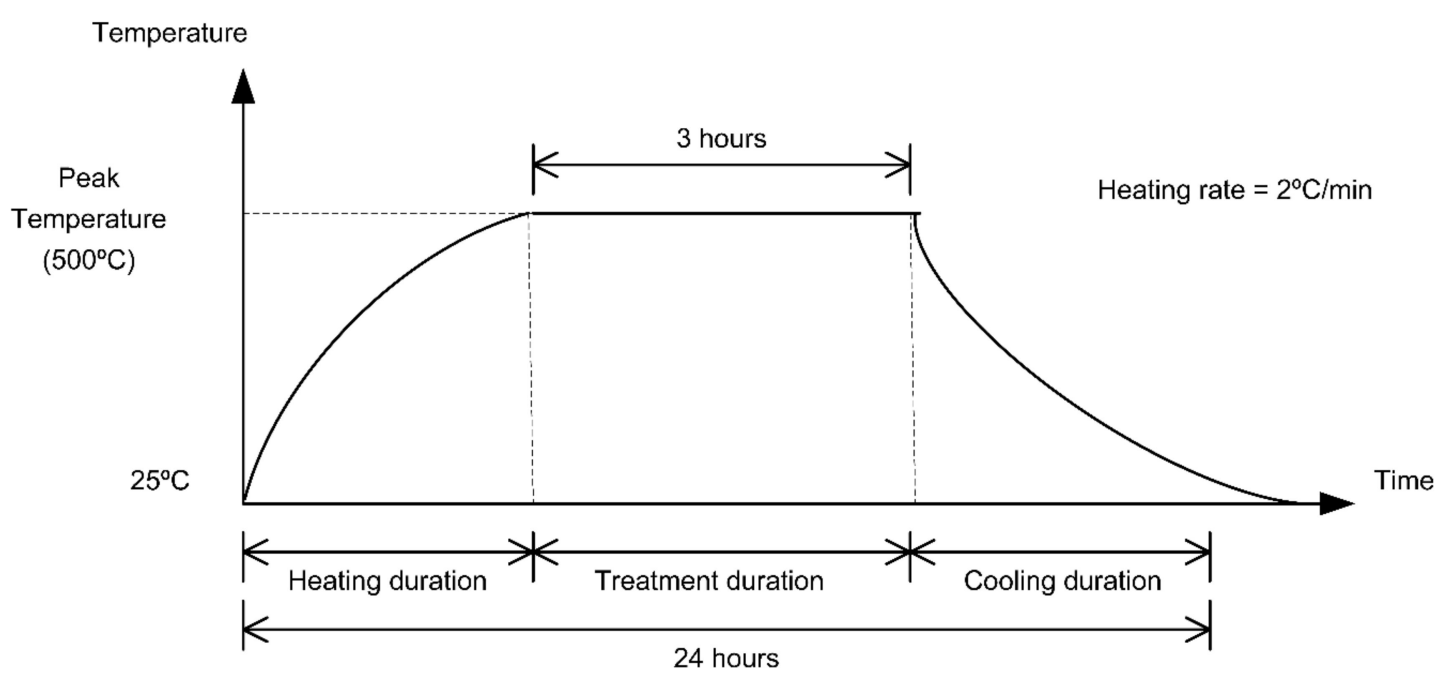

Figure 2. A schematic heating profile of the tested concrete specimens.

Both specimen groups (stored at a room temperature of $25^{\circ} \mathrm{C}$ and subjected to a high temperature of $500{ }^{\circ} \mathrm{C}$ ) were characterized by mechanical testing to determine their compressive strengths, tensile strengths (via diametral compression testing), flexural tensile strengths, and elastic moduli. To measure the compressive strength, five non-heated and five heated cylindrical specimens of each concrete type (including 10 CC specimens and 10 specimens from each SFRC group with a total of 40 specimens) were compression tested. The testing procedure (Figure 3a) was performed using the universal testing machine, and the specimens were tested at a loading speed of $0.5 \mathrm{MPa} / \mathrm{s}$. The specimen bases were regularized using neoprene caps with metallic bases. To determine the tensile strength by diametral compression testing (Figure 3c), three non-heated and three heated cylindrical specimens prepared from each concrete mixture were tested using the same experimental setup at a load speed of $0.2 \mathrm{MPa} / \mathrm{s}$. The flexural tensile strength (Figure 3d) was measured using two non-heated and two heated prismatic specimens for each concrete mixture at a load speed of $0.1 \mathrm{MPa} / \mathrm{s}$. To determine the static (Figure 3b) and dynamic elastic moduli (Figure 3e), two non-heated and two heated cylindrical specimens fabricated from each concrete mixture were tested. In the forced resonant frequency dynamic modulus test, two specimens were tested, and the apparent specific mass was calculated, using a longitudinal mode resonant frequency test system. To determine the frequency field to be used, the approximate longitudinal resonant frequency value of $10 \mathrm{KHz}$ was adopted for cylindrical specimens of $100 \mathrm{~mm}$ diameter and $200 \mathrm{~mm}$ height, and for each specimen, there were 10 readings of the resonant frequency totaling 20 readings. Based on the approximate longitudinal resonant frequency, frequency values were defined for the extremes of the frequency range, i.e., the start frequency (Fs) and end frequency $(\mathrm{Fe})$. These values are used to calculate the respective dynamic modulus of elasticity $\left(E_{D}\right)$, according to Equation (1):

$$
E_{D}=4 n^{2} l^{2} \rho 10^{-12}
$$

where " $n$ " is the fundamental mode frequency of longitudinal vibration in $\mathrm{Hz}$, " $l$ " is the length of the specimen in $\mathrm{mm}$, and " $\rho$ " is the density of the material in $\mathrm{kg} / \mathrm{m}^{3}$.

From the obtained flexural strengths, the values of the flexural toughness $\left(T_{3}\right.$, in $\left.\mathrm{N} \times \mathrm{mm}\right)$ and flexural toughness factor $\left(f_{e, 3}\right.$, dimensionless) were determined. The first parameter was computed in accordance with the Japan Society of Civil Engineers - JSCE criterion SF-4 [64] by measuring the total area under the displacement load curve (load versus strain) with the upper displacement limit equal to $L / 150(3 \mathrm{~mm})$, where $L(450 \mathrm{~mm})$ was the length of the gap between the supports. Thus, toughness 
represents the product between the load $(\mathrm{N})$ and deflection $(\mathrm{mm})$. Afterwards, the value of flexural toughness $\left(T_{3}\right)$ was used in Equation (2):

$$
f_{e, 3}=\frac{T_{3} \cdot L}{\frac{L}{150} \cdot b \cdot h^{2}}
$$

where " $b$ " is the width of the specimen, and " $h$ " is its height. Using this equation, the flexural toughness factor $\left(f_{e, 3}\right)$ corresponding to the mean dummy load resisted by the specimen after the cracking of the cement matrix was obtained [65]. The toughness factor is a parameter that disregards the geometry of the specimen, thus analyzing the energy absorption capacity in the material rupture.
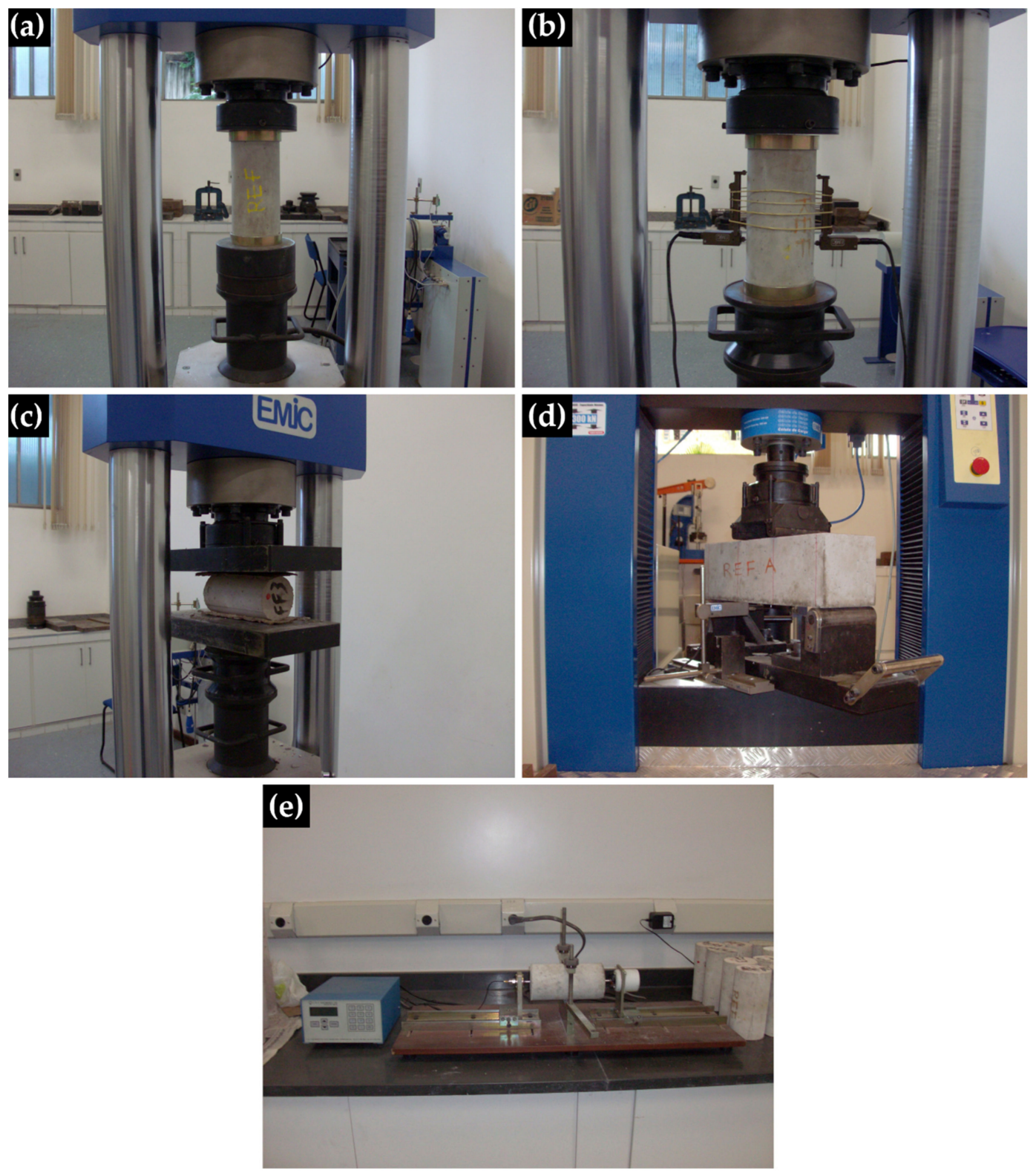

Figure 3. Testing setups for (a) axial compression, (b) static moduli, (c) diametral compression, (d) bending, and (e) dynamic moduli.

\section{Results}

Figure 4 shows the results of compressive strength testing of the concrete specimens obtained before and after heating. The SFRC-AR44_25 ${ }^{\circ} \mathrm{C}$ sample exhibited a slightly higher strength than 
that of CC_ $25{ }^{\circ} \mathrm{C}$ (by approximately $3 \%$ ). The compressive strength was not significantly reduced due to the addition of fibers. Strength reductions were on the order of $7 \%$ and $19 \%$ respectively for SFRC-AR60_25 ${ }^{\circ} \mathrm{C}$ and SFRC-AR80_25 ${ }^{\circ} \mathrm{C}$. Several parameters can change the compressive strength of the material, such as load application speed, environmental conditions, curing and capping methods, which can generate a value distinction of $20 \%$, thus demonstrating that the addition of fibers does not generate significant changes in compressive strength [66-68]. It is generally assumed that the reduction in the SFRC compression strength with an increase in the fiber AR before heating is related to the loss of concrete workability in the fresh state due to the fiber insertion and increase in the fiber length [8]. The strengths of the SFRC-AR44_500 ${ }^{\circ} \mathrm{C}$, SFRC-AR67_500 ${ }^{\circ} \mathrm{C}$, and SFRC-AR800_500 ${ }^{\circ} \mathrm{C}$ specimens exceeded that of CC_500 ${ }^{\circ} \mathrm{C}$ by approximately $45 \%, 53 \%$, and $46 \%$, respectively. A comparison of the compressive strengths obtained for the non-heated and heated concrete samples showed that their magnitudes were significantly reduced; however, the residual compressive strengths of the steel fiber-reinforced concretes were higher than the values obtained for the non-fibrous ones. Thus, the strength of the CC_500 ${ }^{\circ} \mathrm{C}$ specimen was equal to $36.5 \%$ of the magnitude measured for CC_25 ${ }^{\circ} \mathrm{C}$, whereas the SFRC-AR44_500 ${ }^{\circ} \mathrm{C}$, SFRC-AR67_500 ${ }^{\circ} \mathrm{C}$, and SFRC-AR80_500 ${ }^{\circ} \mathrm{C}$ samples had residual compressive strengths equal to $52 \%, 60 \%$, and $65 \%$ of the values obtained for the respective unheated $\left(25^{\circ} \mathrm{C}\right)$ reinforced concretes, indicating that loss reduction occurred with an increase in the AR of the reinforcement fibers. Although the obtained residual mechanical strengths were very close, and the AR of the fibers did not apparently influence the measurement results obtained for the heated samples, the workability loss in the fresh state with increasing fiber length and related reduction in the compressive strength [8] were effectively eliminated. Since the residual mechanical properties of the hot material do not differ significantly in the temperature range of $200-600{ }^{\circ} \mathrm{C}$ [69], the prepared SFRC possesses better abilities to endure exposures to a temperature of $500^{\circ} \mathrm{C}$ as compared to those of ordinary concrete.

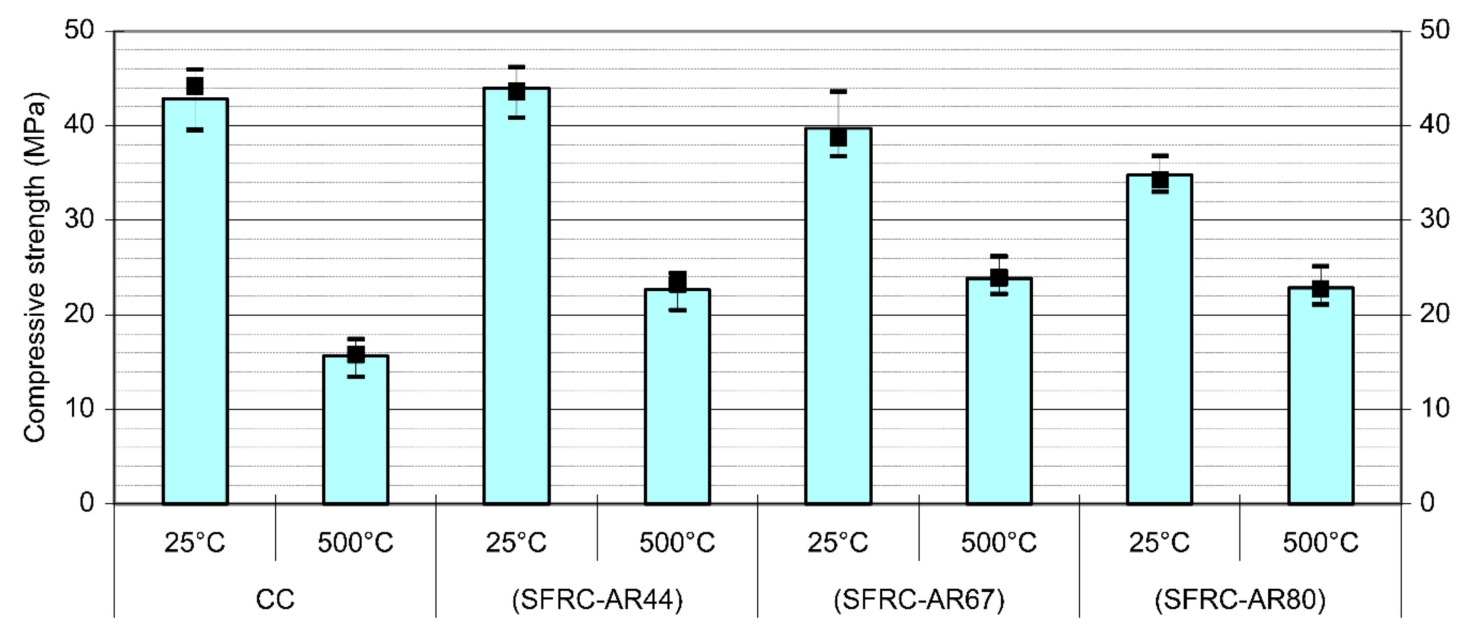

Figure 4. Compressive strengths of various concrete specimens.

Figure 5 shows the results of diametral compression and flexural strength testing. They show that the addition of steel fibers to concrete significantly increases its flexural strength, which becomes further improved with increasing AR [70]. The diametral compression strengths of the SFRC-AR44_25 ${ }^{\circ} \mathrm{C}$, SFRC-AR67_25 ${ }^{\circ} \mathrm{C}$, and SFRC-AR80_25 ${ }^{\circ} \mathrm{C}$ specimens were greater than that of CC_ $25^{\circ} \mathrm{C}$ by $77 \%, 128 \%$, and $98 \%$, respectively. Further, the flexural strengths of the SFRC-AR $44 \_25^{\circ} \mathrm{C}$, SFRC-AR67_25 ${ }^{\circ} \mathrm{C}$, and SFRC-AR80_25 ${ }^{\circ} \mathrm{C}$ samples were $8 \%$, 85\%, and $123 \%$ higher than that of CC_ $25^{\circ} \mathrm{C}$, respectively. However, the SFRC-AR44_500 ${ }^{\circ} \mathrm{C}$, SFRC-AR67_500 ${ }^{\circ} \mathrm{C}$, and SFRC-AR80_500 ${ }^{\circ} \mathrm{C}$ specimens demonstrated diametral compression strengths that were approximately $105 \%, 149 \%$, and $154 \%$ greater than that of CC_500 ${ }^{\circ} \mathrm{C}$ and flexural strengths that were approximately $56 \%, 216 \%$, and $208 \%$ higher than that of CC_500 ${ }^{\circ} \mathrm{C}$, respectively. The residual diametral compression strength of the CC_500 ${ }^{\circ} \mathrm{C}$ sample was equal to $53 \%$ of that of $\mathrm{CC} \_25^{\circ} \mathrm{C}$, and the residual diametrical compression 
strengths of the SFRC-AR44_500 ${ }^{\circ} \mathrm{C}$, SFRC-AR67_500 ${ }^{\circ} \mathrm{C}$, and SFRC-AR80_500 ${ }^{\circ} \mathrm{C}$ specimens were equal to $61 \%, 58 \%$, and $68 \%$ of the strengths of their respective unheated concretes $\left(25^{\circ} \mathrm{C}\right)$. Furthermore, the residual flexural strengths of the heated $\left(500{ }^{\circ} \mathrm{C}\right.$ ) concretes were equal to $42 \%, 61 \%, 54 \%$, and $45 \%$ of the corresponding magnitudes measured for the unheated concretes, respectively. The obtained results indicate that SFRC possesses higher flexural and diametral compression strengths than those of non-fibrous concrete before and after heating, and that their values increase with increasing fiber length (except for the SFRC-80 specimen in the diametral compression strength). Another important advantage of SFRC is that its flexural and diametral compression strengths are equal to or higher than those of non-fibrous concrete, indicating that at temperatures as high as $500{ }^{\circ} \mathrm{C}$ (caused by fire), SFRC would retain its ability to endure mechanical loads that could be sustained by the fiberless concrete before the fire, thus contributing to the safety of the fabricated structures.

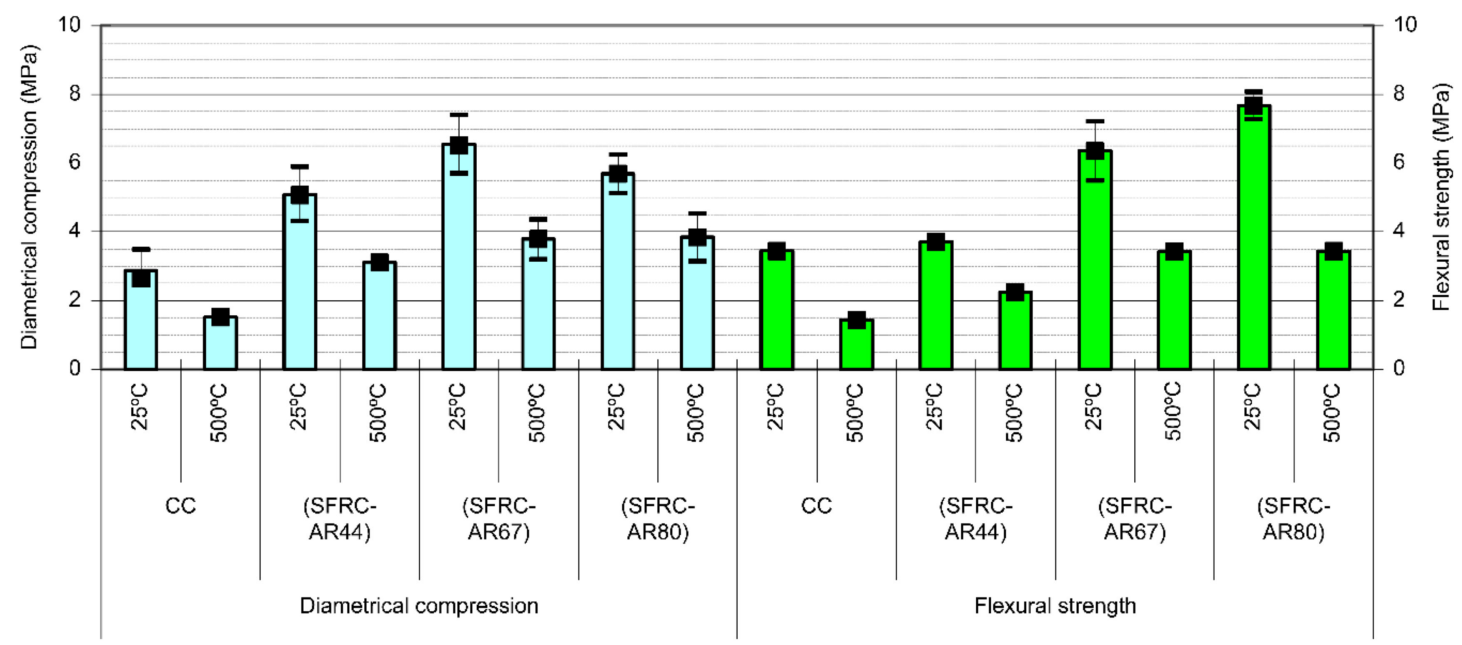

Figure 5. Diametral compression and flexural strengths of the non-fibrous and fiber-reinforced concrete specimens.

Figure 6 shows the static and dynamic elastic moduli measured for the non-fibrous and fiber-reinforced concrete, indicating the absence of any significant differences between the values obtained for the concrete specimens exposed to the same temperatures. According to the results of previous studies, the elastic modulus of the fiber-reinforced concrete increases until the AR of the steel fibers reaches 50 (AR 50) and then starts gradually decreasing after exceeding this value [71]. In this work, a similar effect was observed for the AR of 44 (AR 44), which was very close to that of the AR 50 specimen; however, no significant effect of the AR on the dynamic elastic modulus was detected. The reductions in the elastic moduli of the studied samples observed after their heating to $500{ }^{\circ} \mathrm{C}$ were very close.

Figure 7 shows the load-deflection curves recorded during the flexural testing of the prismatic $150 \times 150 \times 500 \mathrm{~mm}$ concrete specimens. The CC samples exhibited typical brittle behavior, while the SFRC specimens demonstrated pseudo-ductile behavior by retaining their residual strengths after a first crack was produced by the applied force. The addition of fibers increased the value of the load required to create a first crack in the studied specimen. Although the higher fiber AR may decrease the values of the compressive strength and elastic modulus, it also increases the toughness and peak strain of SFRC, which lead to the absorption of a greater amount of energy and better crack control properties [72]. All the studied concrete specimens exhibited a loss of the load capacity after fire; however, its magnitudes obtained for the reinforced concrete specimens were significantly smaller. The SFRC-AR67_500 ${ }^{\circ} \mathrm{C}$ and SFRC-AR80_500 ${ }^{\circ} \mathrm{C}$ samples exhibited maximum loads that were equal to or higher than that of CC_25 ${ }^{\circ} \mathrm{C}$, indicating that the SFRC specimens with fibers AR 67 and 80 retained their flexural strengths after heating at the levels equivalent to the value obtained for the non-fibrous concrete before heating. However, the data presented in Figure 7 confirm that these SFRC 
samples also preserved the ability to sustain high loads after reaching maximum loading during long-term deflections.

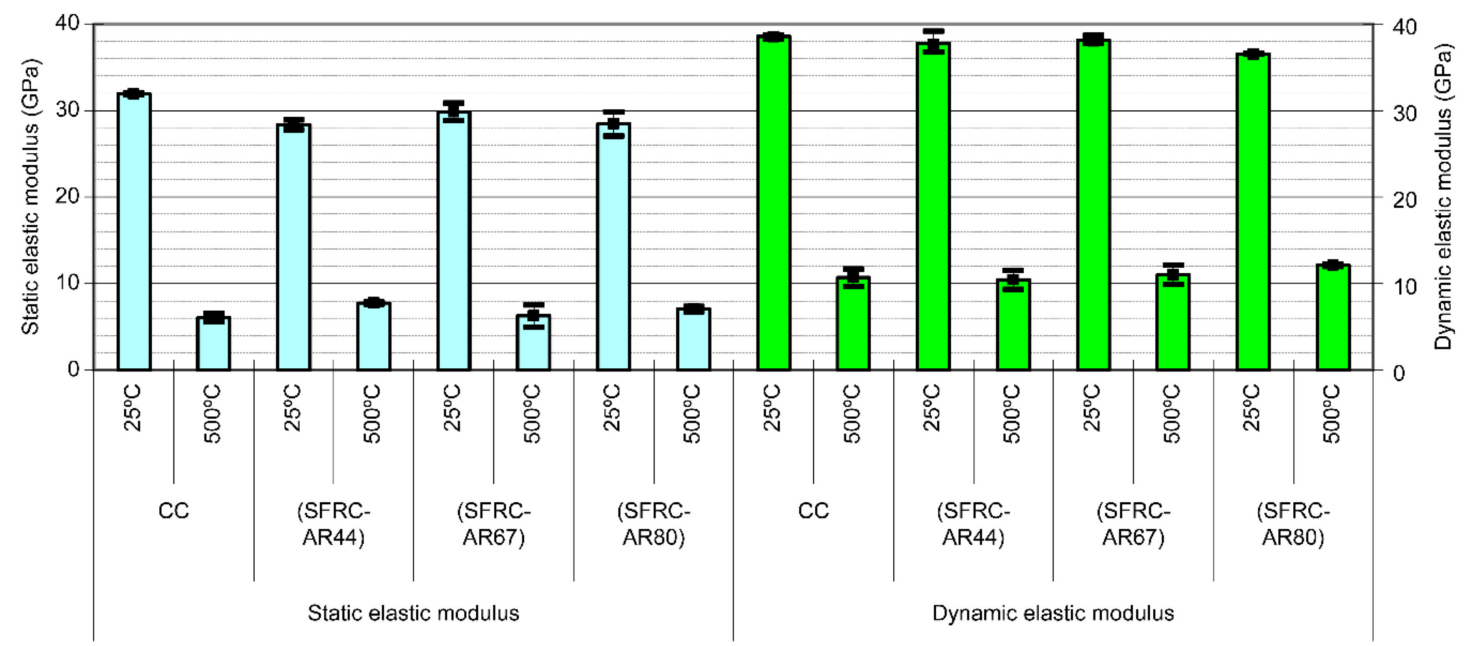

Figure 6. Static and dynamic elastic moduli of the non-fibrous and fiber-reinforced concrete specimens.
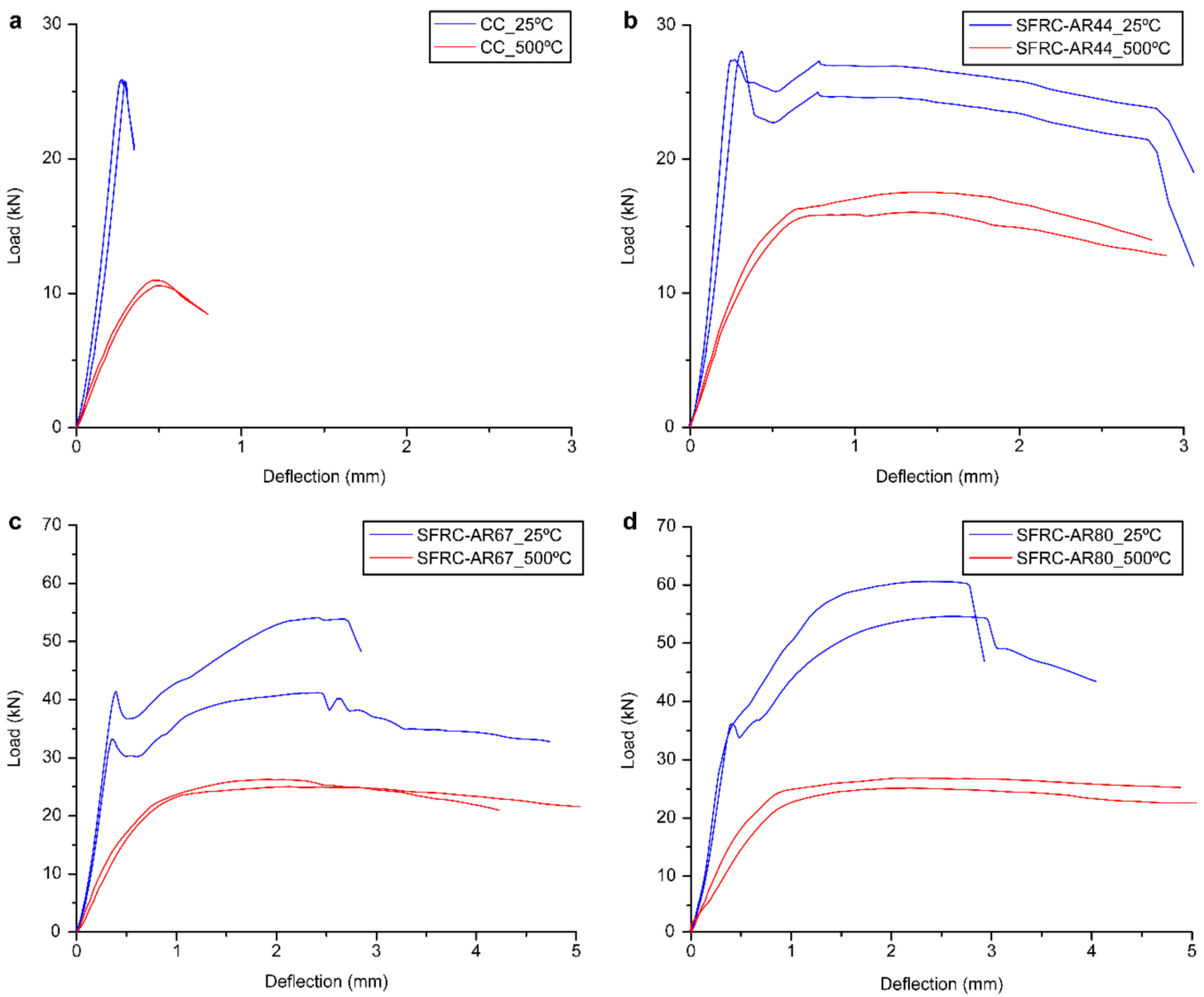

Figure 7. Load-deflection curves recorded for various concrete specimens for flexural tests. (a) CC;

(b) SFRC-AR44; (c) SFRC-AR67; and (d) SFRC-AR80

Figure 8 shows the magnitudes of flexural toughness and the flexural toughness factor obtained for the non-fibrous and fiber-reinforced concrete specimens, which increased with increasing AR. However, the flexural toughness of the CC specimen was relatively small. The flexural toughness values obtained for the SFRC-AR44 and SFRC-AR67 samples after heating to $500{ }^{\circ} \mathrm{C}$ were approximately $57 \%$ of the 
magnitudes measured before heating (for FRC80, this parameter was equal to $46 \%$ ). Thus, the ability to retain high residual compressive strengths (Figure 4), residual flexural strengths (Figure 5), and residual tenacities (Figure 8) after heating makes SFRC a safer material with enhanced fire properties as compared to those of CC.

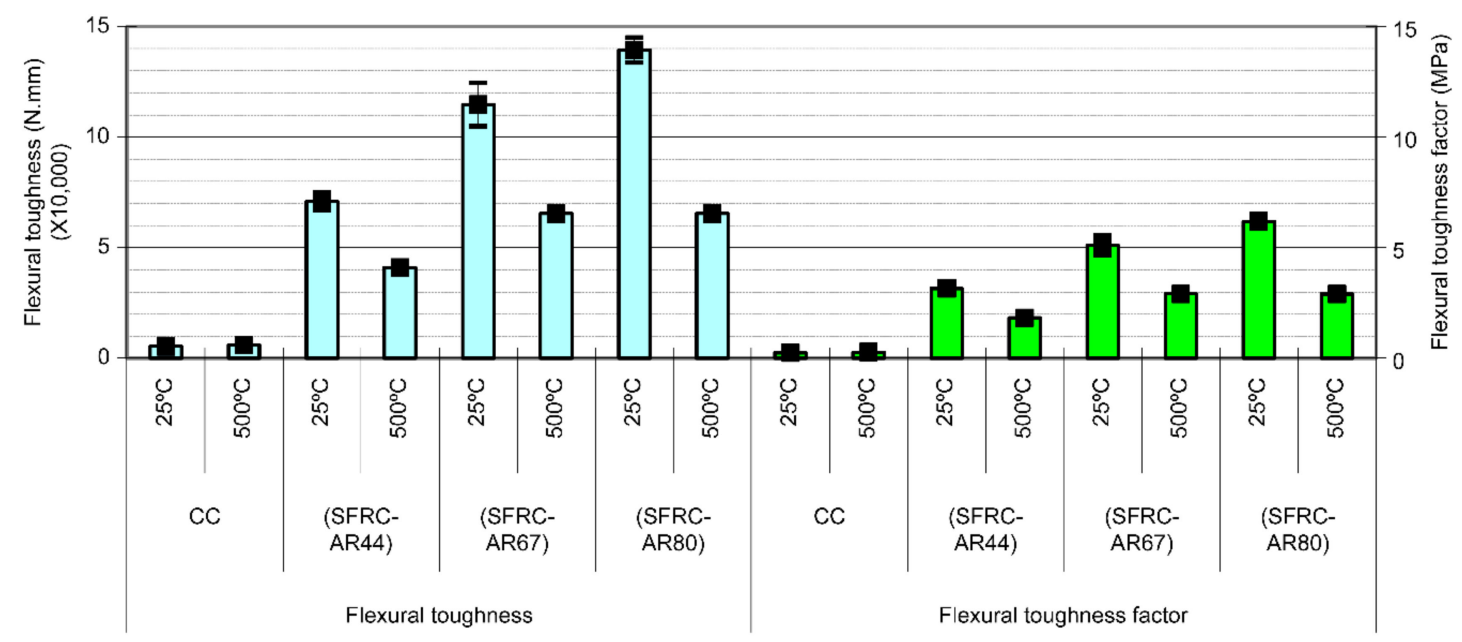

Figure 8. Flexural toughness and flexural toughness factor values obtained for various concrete specimens.

\section{Discussion}

The investigation of the effect of the fiber dimensions on the mechanical properties of the resulting aggregates revealed that the optimal AR of the fibers was 67 (length $=50 \mathrm{~mm}$ ). This result was in good agreement with the data reported by Sarzalejo et al. [73], who suggested that the length of the selected fibers must be twice as long as the maximum dimension of the aggregates with a $20 \%$ tolerance. For the tensile strength (measured by diametral compression testing) as well as flexural tensile strength, the fibers with an AR of 44 (length $=33 \mathrm{~mm}$ ) did not meet the criterion, suggesting that the selected fiber must be longer than twice the maximum dimension of the aggregates with a 20\% tolerance [73]. The evaluation of the fiber length and minimum dimension of the structural elements for the cylindrical specimens showed that the lengths of the three types of fibers satisfied the dimensional criteria proposed by Sarzalejo et al. [73] by being at least 1.5 times smaller than the specimens' diameters. However, the size of the fibers with an AR of 80 (length $=60 \mathrm{~mm}$ ) was very close to this limit. The evaluation of the fiber length and minimum dimension of the structural elements for the prismatic specimens revealed that all the three fiber types satisfied this requirement [73]. It is generally assumed that the inhibition of concrete spalling during fire occurs due to the addition of steel fibers [74]; however, this does not increase the compressive strength and elastic modulus of the concrete matrix, but rather increases its diametral compression and flexural tensile strengths. Furthermore, the addition of steel fibers to concrete changes its behavior from brittle to pseudo-ductile and thus ensures relatively low losses of its mechanical properties at high temperatures (as compared with those of non-fibrous concrete).

\section{Conclusions}

The present work addresses the synergistic effect of the steel fiber aspect ratio and heating on the mechanical behavior of concretes. The following conclusions were observed from the results and discussions:

- The addition of steel fibers contributes to the increased tensile strength in diametrical compression;

- The addition of steel fibers contributes to the increase of the flexural strength; 
- The investigation concluded that concrete reinforced with steel fibers has a much higher residual mechanical behavior after the fires when compared to non-reinforced concretes.

- $\quad$ The increase in fiber length leads to higher residual strength after fire.

- It was observed that the addition of fibers did not promote relevant variations in the compressive strength of the analyzed models. The addition of fibers of different aspect ratios did not significantly change the compressive strength when compared to the variations observed in the literature given by the different molding processes, curing, and load application speed.

- Therefore, it can be concluded that the use of steel fibers in concrete-based materials significantly enhances their fire and hear-resistant characteristics.

The present work suggests as future research the following topics:

- Evaluation of the chipping inhibition of concretes in fire situations by the addition of steel fibers;

- Evaluation of the mechanical properties of steel fiber-reinforced concrete during fires; and

- Finite element simulation of the mechanical behavior of steel fiber-reinforced concrete during fires.

Author Contributions: All the authors contributed to the research. Conceptualization, A.C.S.B. and P.R.C.; Data curation, P.S.M. and E.C.S.C.; Formal analysis, P.R.C.; Funding acquisition, A.C.S.B and M.T.P.A.; Investigation, P.S.M. and E.C.S.C.; Methodology, A.C.S.B.; Project administration, P.R.C.; Resources, A.C.S.B. and M.T.P.A.; Supervision, A.C.S.B., M.T.P.A., and P.R.C.; Validation, A.C.S.B.; Writing - original draft, P.R.R.S.J.; Writing一review and editing, A.C.S.B. and P.R.R.S.J.

Funding: This work was supported by the Minas Gerais State Research Foundation (FAPEMIG) for funding (TEC APQ-02447-13 and TEC APQ-03739-16).

Conflicts of Interest: The authors declare no conflict of interest. The funders had no role in the design of the study; in the collection, analyses, or interpretation of data; in the writing of the manuscript, or in the decision to publish the results.

\section{References}

1. Nawy, E.G. Fundamentals of High Strength High Performance Concrete; Longman: Hong Kong, China, 1996.

2. Kinnunen, S.; Nylander, H.S.E. Punching of Concrete Slabs Without Shear Reinforcement; Royal Institute of Technology: Stockholm, Sweden, 1960.

3. Mckee, D.C. The Properties of an Expansive Cement Mortar Reinforced with Random Wire Fibers. Ph.D. Thesis, University of Illinois, Urbana-Champaign, IL, USA, 1969.

4. Nielsen, L.E.; Chen, P.E. Young's modulus of composites filled with randomly oriented fibers. J. Mater. 1968, 3, 352-358.

5. Romualdi, J.P.; Mandel, J.A. Tensile Strength of Concrete Affected by Uniformly Distributed and Closely Spaced Short Lengths of Wire Reinforcement. J. Proc. 1964, 61, 657-672.

6. Shah, S.P.; Rangan, B.V. Fiber Reinforced Concrete Properties. J. Proc. 1971, 68, 126-137.

7. Shah, A.A.; Ribakov, Y. Recent trends in steel fibered high-strength concrete. Mater. Des. 2011, 32, $4122-4151$. [CrossRef]

8. Mohammadi, Y.; Singh, S.P.; Kaushik, S.K. Properties of steel fibrous concrete containing mixed fibres in fresh and hardened state. Constr. Build. Mater. 2008, 22, 956-965. [CrossRef]

9. Khorami, M.; Ganjian, E. Comparing flexural behaviour of fibre-cement composites reinforced bagasse: Wheat and eucalyptus. Constr. Build. Mater. 2011, 25, 3661-3667. [CrossRef]

10. Shafigh, P.; Mahmud, H.; Jumaat, M.Z. Effect of steel fiber on the mechanical properties of oil palm shell lightweight concrete. Mater. Des. 2011, 32, 3926-3932. [CrossRef]

11. Shokrieh, M.M.; Heidari-Rarani, M.; Shakouri, M.; Kashizadeh, E. Effects of thermal cycles on mechanical properties of an optimized polymer concrete. Constr. Build. Mater. 2011, 25, 3540-3549. [CrossRef]

12. Won, J.-P.; Park, C.-G.; Lee, S.-J.; Kang, J.-W. Bonding characteristics of recycled polyethylene terephthalate (PET) fibers coated with maleic anhydride grafted polypropylene in cement-based composites. J. Appl. Polym. Sci. 2011, 121, 1908-1915. [CrossRef] 
13. Grandhaie, F.; Granju, J.L.; Ringot, E. Durability of pavement repairs: Point of view about the role of fibers. In Proceedings of the 5th International Conference on Concrete Pavement Design and Rehabilitation, West Lafeyette, IN, USA, 23-25 April 1993; Volume 2, pp. 195-202.

14. Granju, J.L. Thin bonded overlays: About the role of fiber reinforcement on the limitation of their debonding. Adv. Cem. Based Mater. 1996, 4, 21-27. [CrossRef]

15. Holanda, K.M.A. Análise Dos Mecanismos Resistentes E Das Similaridades De Efeitos Da Adição De Fibras De Aço Na Resistência E Na Ductilidade à Punção De Lajes-Cogumelo E Ao Cisalhamento De Vigas De Concreto [Analysis of Resistant Mechanisms and Similarities of the Effect of Added Steel Fibres on the Strength and Ductility to both the Punching Shear of Flat Slabs and the Shear Of Concrete Beams]. Ph.D. Thesis, University of São Paulo, São Paulo, Brazil, 2002.

16. Turatsinze, A.; Granju, J.-L.; Sabathier, V.; Farhat, H. Durability of bonded cement-based overlays: Effect of metal fibre reinforcement. Mater. Struct. 2005, 38, 321-327. [CrossRef]

17. Bentur, A.; Mindess, S. Fibre Reinforced Cementitious Composites; CRC Press: Boca Raton, FL, USA, 2006.

18. Liu, Q.; Li, B.; Schlangen, E.; Sun, Y.; Wu, S. Research on the Mechanical, Thermal, Induction Heating and Healing Properties of Steel Slag/Steel Fibers Composite Asphalt Mixture. Appl. Sci. 2017, 7, 1088. [CrossRef]

19. Corradi, M.; Castori, G.; Sisti, R.; Borri, A.; Pesce, G.L. Repair of Block Masonry Panels with CFRP Sheets. Materials 2019, 12, 2363. [CrossRef] [PubMed]

20. Jeong, Y.; Kim, W.; Gribniak, V.; Hui, D. Fatigue Behavior of Concrete Beams Prestressed with Partially Bonded CFRP Bars Subjected to Cyclic Loads. Materials 2019, 12, 3352. [CrossRef]

21. Li, L. Stress-Rupture of Fiber-Reinforced Ceramic-Matrix Composites with Stochastic Loading at Intermediate Temperatures. Part I: Theoretical Analysis. Materials 2019, 12, 3123. [CrossRef]

22. Kotsovos, G.; Zeris, C.; Kotsovos, M. The effect of steel fibres on the earthquake-resistant design of reinforced concrete structures. Mater. Struct. 2007, 40, 175-188. [CrossRef]

23. Chalioris, C.E.; Sfiri, E.F. Shear Performance of Steel Fibrous Concrete Beams. Procedia Eng. 2011, 14, 2064-2068. [CrossRef]

24. Chalioris, C.E. Analytical approach for the evaluation of minimum fibre factor required for steel fibrous concrete beams under combined shear and flexure. Constr. Build. Mater. 2013, 43, 317-336. [CrossRef]

25. Park, J.-S.; Kim, Y.; Cho, J.-R.; Jeon, S.-J. Early-Age Strength of Ultra-High Performance Concrete in Various Curing Conditions. Materials 2015, 8, 5537-5553. [CrossRef]

26. Kang, S.-H.; Lee, J.-H.; Hong, S.-G.; Moon, J. Microstructural Investigation of Heat-Treated Ultra-High Performance Concrete for Optimum Production. Materials 2017, 10, 1106. [CrossRef]

27. Chalioris, C.E.; Panagiotopoulos, T.A. Flexural analysis of steel fibre-reinforced concrete members. Comput. Concr. 2018, 22, 11-25.

28. Guerini, V.; Conforti, A.; Plizzari, G.; Kawashima, S. Influence of Steel and Macro-Synthetic Fibers on Concrete Properties. Fibers 2018, 6, 47. [CrossRef]

29. Chalioris, C.E.; Kosmidou, P.-M.K.; Karayannis, C.G. Cyclic Response of Steel Fiber Reinforced Concrete Slender Beams; an Experimental Study. Materials 2019, 12, 1398. [CrossRef] [PubMed]

30. Soares Junior, P.R.R.; Maciel, P.S.; Barreto, R.R.; da Silva Neto, J.T.; Siqueira Corrêa, E.C.; da Bezerra, A.C.S. Thin Slabs Made of High-Performance Steel Fibre-Reinforced Cementitious Composite: Mechanical Behaviour, Statistical Analysis and Microstructural Investigation. Materials 2019, 12, 3297. [CrossRef]

31. Gencel, O.; Brostow, W.; Datashvili, T.; Thedford, M. Workability and Mechanical Performance of Steel Fiber-Reinforced Self-Compacting Concrete with Fly Ash. Compos. Interfaces 2011, 18, 169-184. [CrossRef]

32. Joshua, D.B.; Ostertag, O. Deflection Hardening and Workability of Hybrid Fiber Composites. ACI Mater. J. 2009, 106, 265-272.

33. Chen, B.; Liu, J. Contribution of hybrid fibers on the properties of the high-strength lightweight concrete having good workability. Cem. Concr. Res. 2005, 35, 913-917. [CrossRef]

34. Sahmaran, M.; Yurtseven, A.; Ozgur Yaman, I. Workability of hybrid fiber reinforced self-compacting concrete. Build. Environ. 2005, 40, 1672-1677. [CrossRef]

35. Hull, W.A.; Ingberg, S.H. Fire resistance of concrete columns. J. Frankl. Inst. 1925, 200, 379-381. [CrossRef]

36. Ingberg, S.H.; Griffin, H.K.; Robinson, W.C.; Wilson, R.E. Fire tests of building columns. J. Frankl. Inst. 1921, 191, 823-827. [CrossRef]

37. Handoo, S.K.; Agarwal, S.; Agarwal, S.K. Physicochemical, mineralogical, and morphological characteristics of concrete exposed to elevated temperatures. Cem. Concr. Res. 2002, 32, 1009-1018. [CrossRef] 
38. Khoury, G.A. Compressive strength of concrete at high temperatures: A reassessment. Mag. Concr. Res. 1992, 44, 291-309. [CrossRef]

39. Barragán, B.E.; Gettu, R.; Martín, M.A.; Zerbino, R.L. Uniaxial tension test for steel fibre reinforced concrete-A parametric study. Cem. Concr. Compos. 2003, 25, 767-777. [CrossRef]

40. Barros, J.A.O.; Figueiras, J.A. Model for the analysis of steel fibre reinforced concrete slabs on grade. Comput. Struct. 2001, 79, 97-106. [CrossRef]

41. Fu, C.Q.; Jin, X.Y.; Jin, N.G. Numerical Experiment on Flexural Properties of Steel Fiber Reinforced Concrete Beam. In Proceedings of the 2009 WRI World Congress on Computer Science and Information Engineering, Los Angeles, CA, USA, 31 March-2 April 2009; Volume 7, pp. 755-759.

42. Hartman, T. Steel Fiber Reinforced Concrete. Ph.D. Thesis, Royal Institute of Technology (KTH), Stockholm, Sweden, 1999.

43. Holschemacher, K.; Mueller, T.; Ribakov, Y. Effect of steel fibres on mechanical properties of high-strength concrete. Mater. Des. 1980-2015 2010, 31, 2604-2615. [CrossRef]

44. Kang, S.-T.; Lee, Y.; Park, Y.-D.; Kim, J.-K. Tensile fracture properties of an Ultra High Performance Fiber Reinforced Concrete (UHPFRC) with steel fiber. Compos. Struct. 2010, 92, 61-71. [CrossRef]

45. Lee, D.H.; Hwang, J.-H.; Ju, H.; Kim, K.S.; Kuchma, D.A. Nonlinear finite element analysis of steel fiber-reinforced concrete members using direct tension force transfer model. Finite Elem. Anal. Des. 2012, 50, 266-286. [CrossRef]

46. Nili, M.; Afroughsabet, V. Combined effect of silica fume and steel fibers on the impact resistance and mechanical properties of concrete. Int. J. Impact Eng. 2010, 37, 879-886. [CrossRef]

47. Nili, M.; Afroughsabet, V. Property assessment of steel-fibre reinforced concrete made with silica fume. Constr. Build. Mater. 2012, 28, 664-669. [CrossRef]

48. Özcan, D.M.; Bayraktar, A.; Şahin, A.; Haktanir, T.; Türker, T. Experimental and finite element analysis on the steel fiber-reinforced concrete (SFRC) beams ultimate behavior. Constr. Build. Mater. 2009, 23, 1064-1077. [CrossRef]

49. Balázs, G.L.; Lublóy, É. Post-heating strength of fiber-reinforced concretes. Fire Saf. J. 2012, 49, $100-106$. [CrossRef]

50. Neville, A.M. Properties of Concrete; Longman: London, UK, 1995; Volume 4.

51. De Sousa Coutinho, A. Fabrico e Propriedades do Betão, 3rd ed.; Laboratório Nacional de Engenharia civil-LNEC: Lisboa, Portugal, 1997.

52. Mehta, P.K.; Monteiro, P.J. Concrete: Microstructure, Properties, and Materials, 3rd ed.; McGraw-Hill: New York, NY, USA, 2006.

53. Cánovas, M.F. Patologia e Terapia do Concreto Armado [Pathology and Therapy of Reinforced Concrete], 1st ed.; PINI: São Paulo, Brazil, 1988.

54. Costa, C.N.; de Figueiredo, A.D.; Silva, V.P. Aspectos Tecnológicos dos Materiais de Concreto em Altas Temperaturas; University of São Paulo-Faculty of Architecture and Urbanism-Department of Architecture Technology: São Paulo, Brazil, 2002.

55. Georgali, B.; Tsakiridis, P.E. Microstructure of fire-damaged concrete. A case study. Cem. Concr. Compos. 2005, 27, 255-259. [CrossRef]

56. Naaman, A.E. Half a century of progress leading to ultra)high performance fiber reinforced concrete: Part 1-Overall review. In Proceedings of the 2nd International RILEM Conference on Strain Hardening Cementitious Composites, Rio de Janeiro, Brazil, 12-14 December 2011; pp. 27-36.

57. Naaman, A.E. Half a century of progress leading to ultra-high performance fiber reinforced concrete: Part 2-Tensile stress-strain response. In Proceedings of the 2nd International RILEM Conference on Strain Hardening Cementitious Composites, Rio de Janeiro, Brazil, 12-14 December 2011; pp. 17-26.

58. Tuyan, M.; Yazıc1, H. Pull-out behavior of single steel fiber from SIFCON matrix. Constr. Build. Mater. 2012, 35, 571-577. [CrossRef]

59. Elavarasi, D.; Saravana Raja Mohan, K.; Parthasarathy, P.; Dinesh, T. Effects of slag on flexural strength of slurry infiltrated fibrous concrete. IOP Conf. Ser. Earth Environ. Sci. 2017, 80. [CrossRef]

60. Sadrmomtazi, A.; Gashti, S.H.; Tahmouresi, B. Residual strength and microstructure of fiber reinforced self-compacting concrete exposed to high temperatures. Constr. Build. Mater. 2020, 230, 116969. [CrossRef]

61. Ferdous, W.; Bai, Y.; Ngo, T.D.; Manalo, A.; Mendis, P. New advancements, challenges and opportunities of multi-storey modular buildings-A state-of-the-art review. Eng. Struct. 2019, 183, 883-893. [CrossRef] 
62. Ferdous, W.; Ngo, T.D.; Nguyen, K.T.Q.; Ghazlan, A.; Mendis, P.; Manalo, A. Effect of fire-retardant ceram powder on the properties of phenolic-based GFRP composites. Compos. Part B Eng. 2018, 155, 414-424. [CrossRef]

63. Ferdous, W.; Manalo, A.; Van Erp, G.; Aravinthan, T.; Ghabraie, K. Evaluation of an Innovative Composite Railway Sleeper for a Narrow-Gauge Track under Static Load. J. Compos. Constr. 2018, 22. [CrossRef]

64. Japan Society of Civil Engineers (JSCE). JSCE-SF4: Method of Tests for Flexural Strength and Flexural Toughness of Fiber Reinforced Concrete; Concrete Library of JSCE, Part III-2; Standards for Test Method of Fiber Reinforced Concrete; Japan Society of Civil Engineers: Tokyo, Japan, 1984; pp. 58-61.

65. Figueiredo, A.D. de Concreto Reforçado Com Fibras [Fiber-Reinforced Concrete]. Ph.D. Thesis, University of São Paulo, São Paulo, Brazil, 2011.

66. American Concrete Institute (ACI). Design Considerations for Steel Fiber Reinforced Concrete. Struct. J. 1988, 85, 563-579.

67. De Figueiredo Maia, A.L.; Oliveira Sena, N.; de Oliveira, L.L.M.S.; Melo Pereira, G.; da Silva, M.J.; Resende, D.S.; da Silva Neto, J.T.; de Aguilar, M.T.P.; Bezerra, A.C.S. Evaluation of Sample Preparation Parameters in the Compressive Strength of Cementitious Composites. Mater. Sci. Forum 2016, 869, 93-97. [CrossRef]

68. Da Bezerra, A.C.S.; Aguilar, M.T.P.; Cetlin, P.R. The influence of specimen capping on the results of compression strength tests of cementitious composites. Rem Rev. Esc. Minas 2012, 65, 291-296. [CrossRef]

69. Bergamini, E.; Colombo, M.; Felicetti, R.; Manzoni, M. On the bending behaviour of SFRC exposed to high temperature. In Proceedings of the 6th International RILEM Symposium on Fibre-Reinforced Concretes (BEFIB’2004), Varenna, Italy, 20-22 September 2005; Di Prisco, M., Felicetti, R.M., Plizzari, G.A., Eds.; pp. 647-658.

70. Yazıc1, Ş.; İnan, G.; Tabak, V. Effect of aspect ratio and volume fraction of steel fiber on the mechanical properties of SFRC. Constr. Build. Mater. 2007, 21, 1250-1253. [CrossRef]

71. Jo, B.-W.; Shon, Y.-H.; Kim, Y.-J. The evalution of elastic modulus for steel fiber reinforced concrete. Russ. J. Nondestruct. Test. 2001, 37, 152-161. [CrossRef]

72. Wang, Z.L.; Wu, J.; Wang, J.G. Experimental and numerical analysis on effect of fibre aspect ratio on mechanical properties of SRFC. Constr. Build. Mater. 2010, 24, 559-565. [CrossRef]

73. Sarzalejo, A.G.; Rossi, B.; Perri, G.; Winterberg, R.; Aristeguieta, R.E.P. Fibras Como Elemento Estrutural Para Reforço de Concreto, (Manual Técnico) [Fibres as Structural Elements for Concrete Reinforcement (Technical Manual)]; Maccaferri do Brasil Ltda: Jundiaí, Brazil, 2009.

74. Da Silva Bezerra, A.C.; Corrêa, E.C.S.; Aguilar, M.T.P.; Cetlin, P.R. Post-fire Behavior of Ordinary Concrete Reinforced with Short Steel Fibers. J. Civ. Eng. Archit. 2015, 9, 262-267. 